\title{
Sonic Exploration of Alto Recorder for Nadi Bumi: Applied Research in Contemporary Classical Music Composition
}

\author{
Ainolnaim Azizol \\ Faculty of Music, Universiti Teknologi Mara \\ Level 11, Menara SAAS, UiTM Main Campus, 40450 Shah Alam, Selangor \\ e-mail: ainolnaim7683@ salam.uitm.edu.my
}

Published online: 30 December 2017

Cite this article (APA): Ainolnaim Azizol (2017). Sonic exploration of alto recorder for Nadi Bumi: Applied research in contemporary classical music composition. Malaysian Music Journal, 6(2), 71-93.

\begin{abstract}
Musical acoustic research has defined acoustic properties of fundamental recorder techniques for sound production that provide valuable insights into the process and techniques of contemporary classical music composition. Nonetheless, the exploration of musical acoustic properties from extended techniques of the recorder, especially for alto recorder, is not distinctly defined, scientifically and artistically. This research aims to: 1) study the scientific and artistic profiles of the alto recorder's extended techniques found in contemporary classical recorder music compositions and 2) discuss newly discovered extended techniques derived from the earlier alto recorder extended techniques. The musical composition of Nadi Bumi is a derivation of applied research based on empirical studies of the earlier and new extended techniques sound production of the instrument. The musical ideas of the piece were associated with bone whistle or flute, Fibonacci series, Schumann Resonance and spectral music techniques. This research employed narrowband short-time Fourier Transform (STFT) spectrogram analysis, absolute scale non-linear decibel loudness seismograph analysis and music composition analysis based on selected score excerpts of contemporary recorder music composition and its controlled audio recording environment of alto recorder sound production sampling. Ultimately, this research enabled sonic exploration of new alto recorder extended techniques and is anticipated to become a reference framework for the future artistic development of alternative alto recorder music compositions.
\end{abstract}

Keywords: acoustic, alto recorder, extended techniques, sonic exploration, spectral music 


\section{Contemporary Classical Music: The Writing Process of Nadi Bumi}

Throughout the experiences of the composer in formal music learning, music composition is a process of organising sound within a time frame in horizontal intervallic motion (rhythm) and vertical intervallic motion (melodic). The combinations of melodic lines in layers produce harmony with various textures, such as homophony, polyphony (counterpoint) and heterophony. These sounds work as a medium or bridge to communicate between composer and listeners, traditionally to express adjective elements such as feelings, textures, colours, and moods. However, the composer opines that in contemporary classical music, conceptual idea and logic are expressed in the music through embedding scientific elements into musical elements, which can be observed in mathematical and computer music. Additionally, the composer believes that in order to write or produce something such as a formula or a prototype music creation, an in-depth study or research encompassing various methods of systematic inquiry on 'how, what, when and why', is thus highly indispensable to solve practical problems which lead to applied research. This involves the action of sampling, observing or experimenting (empirical) and analysing, to name a few, in terms of discerning qualitative data, quantitative data, or both. Nadi Bumi was composed as a quasialeatoric and spectral music piece for amplified alto recorder in $\mathrm{F}$. The piece was written for New Recorder Music 2016 (a composition competition) organised by Association Flauto Dolce Lausanne and was premiered at Church Saint-Laurent in Switzerland.

\section{Recorder}

The recorder is a Western traditional end-blown aerophone instrument with a whistle mouthpiece, also known as internal-duct flute or fipple flute. The instrument has existed since the Iron Age and is among the earliest surviving instruments dating back to Middle Ages (documented in the Netherlands in 1940). Today, the recorder is available in a wide variety of ranges (Table 1) with different sizes, materials, designs and central or fundamental pitch tunings. Baroque and contemporary recorders have relatively similar designs, shaped with a tapered bore, consisting of three joint parts: 1) mouthpiece head or the upper joint with internal cylindrical bore, 2) middle joint and 3) the foot joint. Conversely, the Renaissance recorder is constructed of a single or two joint parts, the upper and foot, with a relatively straight cylindrical pipe (O’Brien and Hass, 1999). 
Table 1

Recorder types, central tunings, lengths, and voice range (Source: O'Brien and Hass, 1999)

\begin{tabular}{l|ccc}
\multicolumn{1}{c|}{ Recorder type or name } & Central tunings & $\begin{array}{c}\text { Length } \\
\text { (metre) }\end{array}$ & $\begin{array}{c}\text { Voice ranges } \\
(\mathbf{C 4} \text { = middle C) }\end{array}$ \\
\hline $\begin{array}{l}\text { Garklein } \\
\text { Sopranino }\end{array}$ & F6 & $0.16-0.18$ & C6 - D8 \\
Soprano or descant & C5 & 0.20 & F5 - G7 \\
Alto & F4 & 0.32 & C5 - D7 \\
Voice flute & D4 & 0.47 & D4 - G6 \\
Tenor & C4 & 0.50 & D4 - A5 \\
Bass & F3 & $0.85-0.89$ & C4 - D6 \\
Great bass & C3 & $1.10-1.15$ & C3 - G5 \\
Contrabass & F2 & 2.00 & F2 - E4 \\
Sub-great bass & C2 & 1.95 & C2 - D3 \\
Sub-contrabass & F1 & $2.40-2.50$ & F1 - G3
\end{tabular}

The alto recorder, also known as the treble recorder, is a non-transposed instrument with a diatonic tuning system of a central pitch of either F4 or G4 (alto recorder in $\mathrm{F}$ or $\mathrm{G})$. These are the fundamental pitches produced by the fipple or whistle mouthpiece of a recorder (open hole fingerings). Alto recorders are available in different sets of temperaments that vary based on the recordists' stylistic preferences, musical repertoire style or genre and musical performance or orchestration settings (Table 2). According to Bennetts et al. (1988), traditional recordists prefer to tune their recorder in just intonation ${ }^{1}$ (JI) rather than in equaltemperement ${ }^{2}$ tuning system for unaccompanied solo repertoire unless the style or genre of the repertoire requires so or is performed in ensemble with other equaltempered instruments such as the piano.

Elder (1964), mentioned that changes in air temperature, humidity and blowing pressure affect the vibrational energy levels of air molecules and musical instrument materials, which significantly alter the tuning of any wind instruments. Nonetheless, the type of alto recorder materials, air temperature, humidity and space acoustics affecting sound production quality (e.g. loudness degree, timbre and tunings), is not a major concern for Nadi Bumi since electronic amplification and 
fine tunings are employed. Furthermore, Nadi Bumi did not specifically indicate any type of tuning system for the recorder.

Table 2

Alto recorder f' (F4) temperament tunings from different Baroque and Renaissance recorder designers and makers used at present (Lander, 1996)

\begin{tabular}{|c|c|c|c|}
\hline $\begin{array}{l}\text { Recorder } \\
\text { types }\end{array}$ & Recorder fingering systems & $\begin{array}{l}\text { Recorder } \\
\text { designers and } \\
\text { makers }\end{array}$ & $\begin{array}{l}\text { Recorder } \\
\text { temperament } \\
\text { tunings }\end{array}$ \\
\hline \multirow[t]{3}{*}{$\begin{array}{l}\text { Renaissance } \\
\text { alto }\end{array}$} & $\begin{array}{l}\text { English fingering system with } \\
\text { double holes on lower notes }\end{array}$ & J. Steenbergen & $\mathrm{A} 4=440 \mathrm{~Hz}$ \\
\hline & & J. Denner & $\begin{array}{l}\mathrm{A} 4=415 \mathrm{~Hz} \\
\mathrm{~A} 4=440 \mathrm{~Hz}\end{array}$ \\
\hline & & P. Bressan & $\begin{array}{l}\mathrm{A} 4=415 \\
\text { A4 }=408 \mathrm{~Hz} \\
\text { A4 }=392 \mathrm{~Hz}\end{array}$ \\
\hline \multirow[t]{5}{*}{ Baroque alto } & $\begin{array}{l}\text { English/ Baroque fingering } \\
\text { system with double holes on } \\
\text { lower notes }\end{array}$ & Stanesby Jr. & $\mathrm{A} 4=415 \mathrm{~Hz}$ \\
\hline & $\begin{array}{l}\text { English / Baroque fingering } \\
\text { system with double holes on } \\
\text { lower notes }\end{array}$ & Rottenburgh & $\begin{array}{l}\mathrm{A} 4=410 \\
\mathrm{~A} 4=415 \mathrm{~Hz}\end{array}$ \\
\hline & $\begin{array}{l}\text { Hotteterre fingering system with } \\
\text { single holes }\end{array}$ & Hotteterre & $\mathrm{A} 4=440 \mathrm{~Hz}$ \\
\hline & $\begin{array}{l}\text { English / Baroque fingering } \\
\text { system with double holes on } \\
\text { lower notes }\end{array}$ & Bizey & $\mathrm{A} 4=392 \mathrm{~Hz}$ \\
\hline & $\begin{array}{l}\text { Ganassi fingering system with } \\
\text { single holes }\end{array}$ & Ganassi & $\begin{array}{l}\text { A4 }=466 \\
\text { A4 }=460 \\
\text { A4 }=440 \\
\text { A4 }=415\end{array}$ \\
\hline
\end{tabular}

\section{Sonic exploration from extended techniques}

According to Burtner (2005), 'extended techniques' refer to non-traditional or unconventional methods of playing musical instruments through which unusual and new sounds are produced in an explorative, experimental and artistic manner. 
O'Kelly (1990) mentioned that extended techniques began to be explored since the 17th-century classical Western art music, and it distinctively developed and became prominent during 20th- and 21st-century contemporary art music through new musical notation symbols, which frequently functioned as a musical sound effect. Recorder extended techniques usually explore spectral or timbral quality in monophonic and multiphonic sounds through manipulation of fingering, embouchure, blowing, vocalised tone, tonguing and prepared techniques. The sonic results of recorder extended techniques can be categorized into two groups; definite and indefinite pitch. Among the first development of extended techniques for alto recorder was Sweet (1964) by Louis Andriessen, a piece dedicated to Frans Bruggen. The composer introduced a highly attacked plosive and percussive playing techniques indicated with a Bartok pizzicato symbol (Figure 1).

After the composer has identified and evaluated all recorder scores and audio recordings that employed extended techniques (Table 3), Meditation (1975) by Ryōhei Hirose (Figure 2), which underlines vocalised tone and embouchure manipulation, was selected as a reference piece for Nadi Bumi musical composition. The sonic aesthetic approach to the extended techniques present in Meditation, which the composer regarded as fluid, ethereal and organic, is similar to the soundworld of Nadi Bumi. These extended techniques were further analysed through scientific profiling to identify the acoustic mechanisms and to develop a new form of extended techniques that align with the artistic idea of Nadi Bumi, which are discussed further.

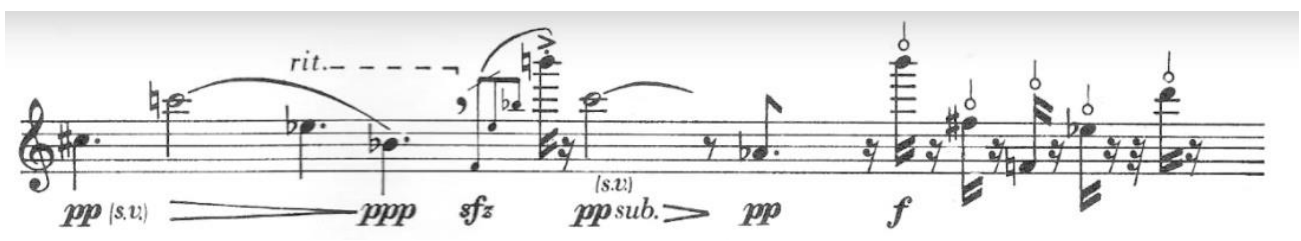

Figure 1. Excerpt of Sweet (1964) by Louis Andriessen with extended technique playing indicated by a musical notation symbol similar to Bartok pizzicato on top of semiquaver notes at the forte (f) passage (Source: TheModernRecorder, 2012) 
Table 3

Contemporary classical music recorder repertoires with extended techniques (Source: Ainolnaim Azizol, 2016)

\begin{tabular}{|c|c|c|c|}
\hline Composer & Title & Instrumentation & Year \\
\hline $\begin{array}{l}\text { Louis } \\
\text { Andriessen }\end{array}$ & Sweet & Alto recorder & 1964 \\
\hline Luciano Berio & Gesti & Alto recorder or Tenor recorder & 1966 \\
\hline $\begin{array}{l}\text { Sylvano } \\
\text { Bussotti }\end{array}$ & $\begin{array}{l}\text { Rara from La } \\
\text { Passion selon Sade }\end{array}$ & Soprano recorder & 1966 \\
\hline $\begin{array}{l}\text { Makoto } \\
\text { Shinohara }\end{array}$ & Fragmente & Tenor recorder & 1968 \\
\hline George Crumb & Lux aeterna & $\begin{array}{l}\text { Soprano, bass flute (doubling } \\
\text { soprano recorder), sitar and two } \\
\text { percussionists }\end{array}$ & 1971 \\
\hline Ryōhei Hirose & Meditation & Alto recorder or Tenor recorder & 1975 \\
\hline Ryōhei Hirose & Lamentation & $\begin{array}{l}\text { Two alto recorder, tenor recorder } \\
\text { and bass recorder }\end{array}$ & 1975 \\
\hline Eugene Bozza & Interlude & $\begin{array}{l}\text { Soprano recorder or Alto recorder } \\
\text { or flute }\end{array}$ & 1978 \\
\hline John Cage & Three & Three recorders (various range) & 1989 \\
\hline Maki Ishii & Black Intention I & Soprano recorder & 1976 \\
\hline Arvo Pärt & $\begin{array}{l}\text { Pari Intervallo } \\
\text { (recorder version) }\end{array}$ & $\begin{array}{l}\text { Soprano recorder, alto recorder, } \\
\text { tenor recorder and bass recorder }\end{array}$ & 1976 \\
\hline Arvo Pärt & Arbos & $\begin{array}{l}\text { Two soprano recorder, two alto } \\
\text { recorder, two tenor recorder, bass } \\
\text { recorder and three triangles (ad } \\
\text { lib.) }\end{array}$ & 1977 \\
\hline Maki Ishi & Black Intention IV & $\begin{array}{l}\text { Two alto recorder, tenor recorder } \\
\text { and bass recorder }\end{array}$ & 1980 \\
\hline
\end{tabular}




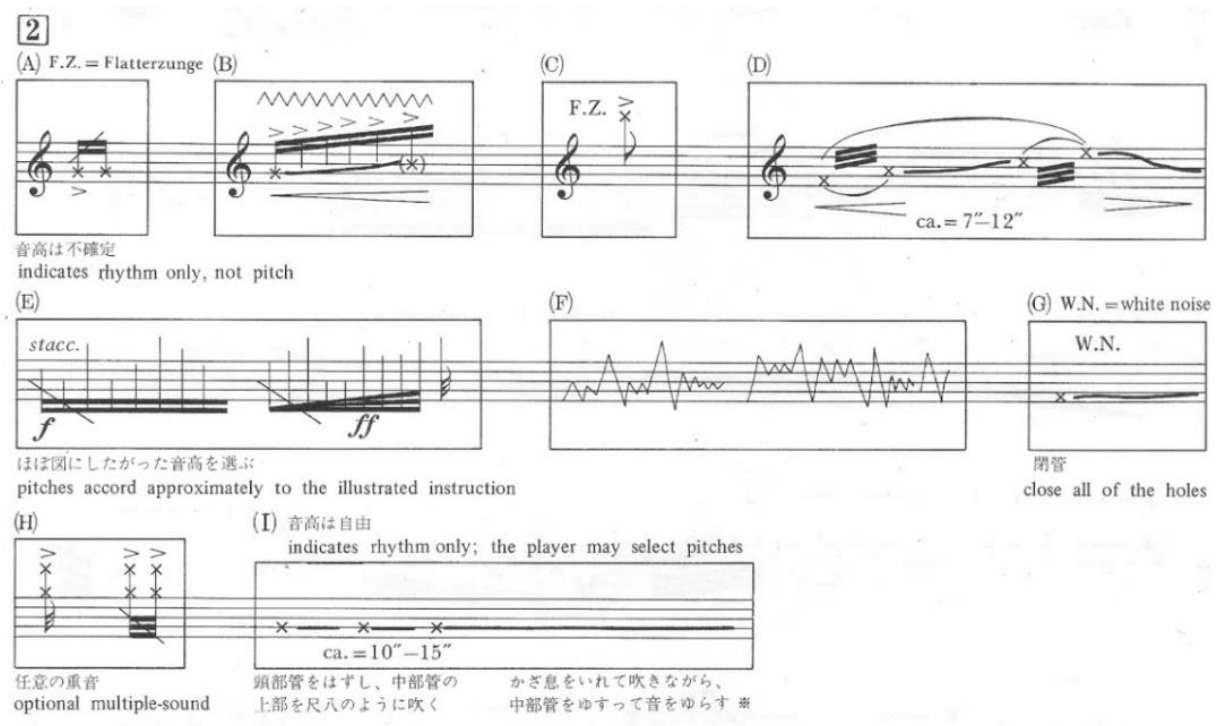

Figure 2. Excerpt of Meditation (1975) by Ryōhei Hirose featuring extended techniques focusing on vocalised tone and embouchure manipulation (Source: TheModernRecorder, 2013)

\section{Data Acquisition}

\section{Fundamental of the recorder's musical acoustics}

Fundamentally, the sound of the recorder is triggered by the air blown from the mouth into the recorder mouthpiece, which is modified according to the manipulation of fingering, embouchure, volume and speed of the blown air stream and tonguing movements. Similar to the descant and tenor recorder, the alto recorder consists of three joint parts: head joint, or top, which acoustically functions as air jet amplifier and resonator, mid joint as acoustic oscillator and foot joint as an acoustic resonator.

According to Elder (1964), the recorder is classified as a musical instrument with a jet-edge resonator. The resonator driver located at the recorder head, which consists of a tapered windway or duct, orifice, lip, window, edge, blade or labium (Figure 3). An air jet stream is produced at the orifice by compressed air blown along the tapered duct. The air jet stream is sliced at the blade edge, generating air turbulence, which follows the Bernoulli principle. The turbulence generates a whistle tone or edge tone and drives the air inside the bore or air column of the recorder mid and foot parts to oscillate, producing an audible standing wave in which the pitch is determined by the wave length along the bore. For this research, the sound production of the instrument was recorded using spot microphone technique with $\mathrm{AKG} \mathrm{C415} \mathrm{B}$ at the open end hole of the acoustic resonator (foot), acoustic oscillator (mid), air jet amplifier-resonator (window-head) and the recordist's mouth. 


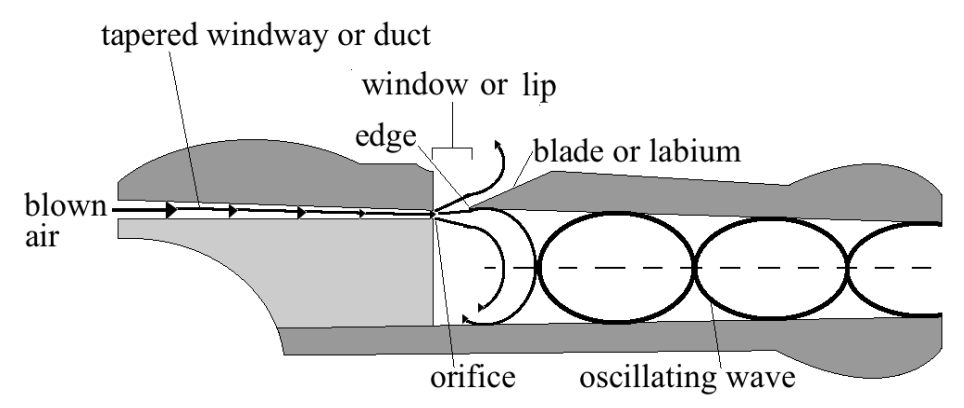

Figure 3. Acoustic mechanism of a recorder (Source: Ainolnaim Azizol, 2016)

\section{Conventional extended techniques}

Extended techniques can be classified into two categories: definite pitch, in which a listener is able to discern and notate the pitch; and indefinite pitch, in which a listener perceives difficulty in identifying the exact pitch. However, the pitch recognition is largely influenced by the fluctuation speed between silence and sound (rhythms), the degree of sound amplitude (dynamics) and the range of frequencies (pitches). For example, in Meditation, pitches in the extended technique of whistling tone can be recognised if slow, steady rhythm and constant dynamic range are performed. In this case, the whistling tone is played ad libitum (freely) in terms of pitch range, dynamic, and rhythms which make the pitches barely recognisable.

During a video rehearsal and discussion of Nadi Bumi via Skype, the recordist, Pauchard (2016) stated that definite pitch in conventional extended techniques for alto recorder are: 1) microtones, 2) multiphonics from non-harmonic distortions, 3) pitch bending at a slow tempo, 4) pitch-based flutter tonguing, 5) definite pitches from headpiece playing and without headpiece playing and 6) definite pitches from circular breathing. Meanwhile, indefinite pitch conventional extended techniques for alto recorder are; 1) multiphonics from harmonic distortions, 2) rapid and irregular rhythm-based sound production, 3) white noise tone, 4) plosive tones, 5) instrument body noise created by hitting and blowing, 6) timbral fluctuation by breath manipulation and prepared technique, 7) indefinite pitched based flutter tonguing, 8) overblown and 9) indefinite pitches from headpiece playing and without headpiece playing.

\section{Audio Sampling and Frequency-Pitch Mapping}

Audio sampling and frequency-pitch mapping methods are applied to provide visual characteristics to respective alto recorder extended techniques sound production for scientific and artistic profiling, which may eventually lead to the development of new alto recorder extended techniques other than new musical notation and acoustic synthesis-physical modeling. The conventional extended techniques for alto recorder sound production was sampled at $44100 \mathrm{~Hz}$ sampling rate and a 16-bit 
depth from a contemporary plastic recorder in F (F4) tuned at A4 $=440 \mathrm{~Hz}$ in welltempered tuning system. The audio sampling system consisted of two AKG C451 B microphones, an AVID Mbox 2 analogue-digital signal converter interface, a Pro Tools $10 \mathrm{HD}$ digital audio workstation and an Izotope Ozone Insight spectrum analyser plugin. The AKG C451 B microphone frequency response was calibrated to nearly flat frequency response (Figures 4 and 5) to achieve non-personalised alto recorder frequency or colour sampling. Absolute scale non-linear decibel loudness seismograph analysis was employed to measure the loudness or sound pressure level (SPL) in decibel (-dB) which affects the frequency-pitch production of alto recorder. The spectrogram described the short-time Fourier transform (STFT) fixed at narrow band linear frequency with 4096 fast Fourier transform (FFT) Hanning window size that enables the display of individual harmonics with uniform frequency spread and good frequency resolutions.

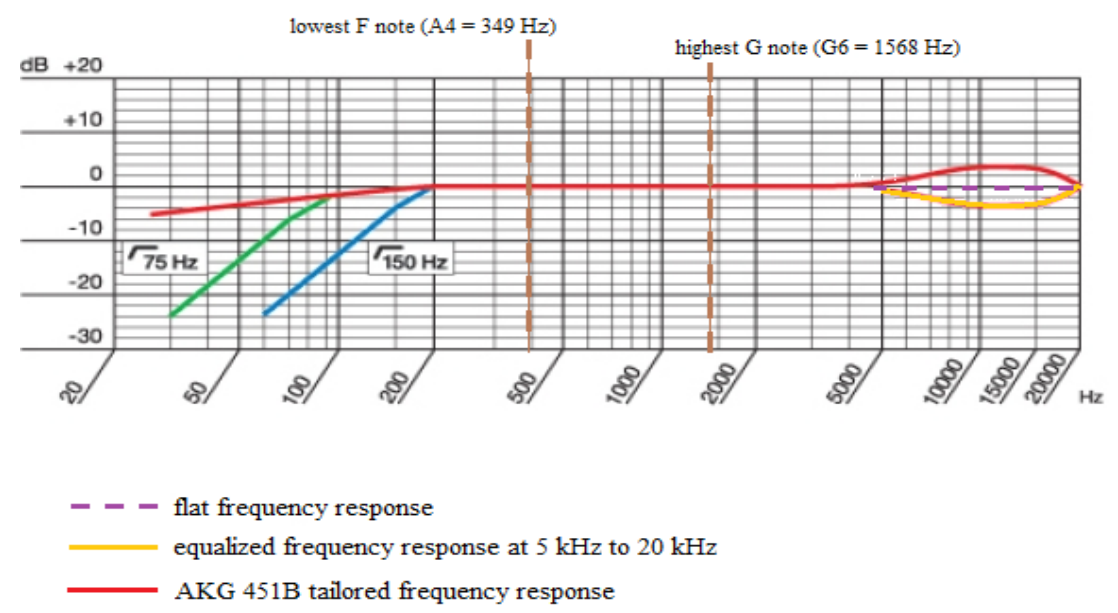

Figure 4. Nearly flat frequency response achieved by equalising AKG 451B microphone tailored frequency response at $5 \mathrm{kHz}$ to $20 \mathrm{kHz}$ (Source: Ainolnaim Azizol, 2016)

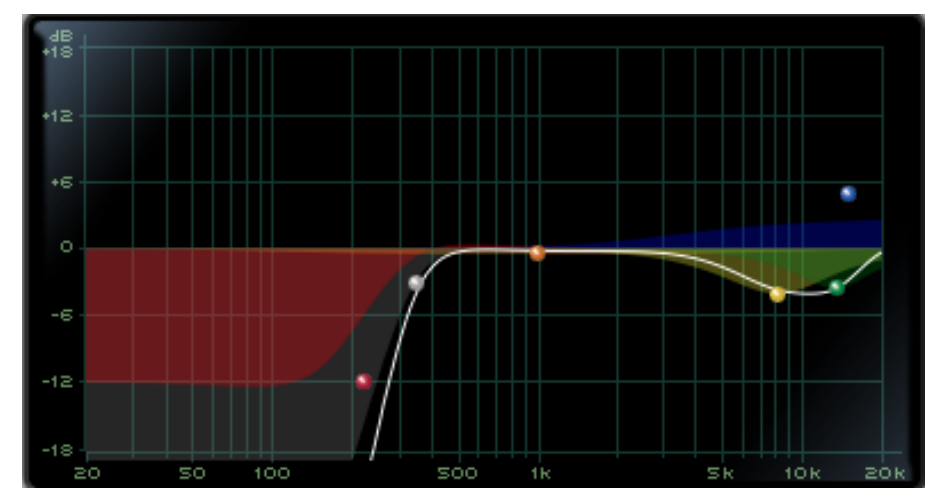


Figure 5. EQ3 7-Band Equalisation with high pass filter (HPF) at $300 \mathrm{~Hz}$ with $24 \mathrm{~dB} /$ octave, and bell curve between $5 \mathrm{kHz}$ to $20 \mathrm{kHz}$ with flat curve belly around $-4 \mathrm{~dB}$ between $1 \mathrm{kH}$ to $15 \mathrm{kHz}$ (Source: Ainolnaim Azizol, 2016)

Table 4

Five new extended techniques derived from multiphonics of alto recorder (Source:

Ainolnaim Azizol, 2016)

\begin{tabular}{l|l} 
Multiphonics Types & Playing Techniques \\
\hline Slap echo multiphonic & $\begin{array}{l}\text { A multiphonic played by flutter tonguing with } \\
\text { suddenly loud playing and gradually fade out. }\end{array}$ \\
$\begin{array}{l}\text { Reverse tape } \\
\text { multiphonic }\end{array}$ & $\begin{array}{l}\text { A multiphonic played by flutter tonguing with } \\
\text { gradually loud playing and gradually fade in. }\end{array}$ \\
$\begin{array}{l}\text { Amplitude modulation } \\
\text { multiphonic }\end{array}$ & $\begin{array}{l}\text { A multiphonic played by alternately increasing } \\
\text { and decreasing the air volume and speed or } \\
\text { alternately open-close the foot hole with palm or } \\
\text { other wind resistant materials. }\end{array}$ \\
$\begin{array}{l}\text { Tremolo multiphonic } \\
\text { A multiphonic played by fingering tremolo and } \\
\text { vocalised tone. }\end{array}$ \\
$\begin{array}{l}\text { Double Tremolo } \\
\text { multiphonics }\end{array}$ & $\begin{array}{l}\text { Two multiphonics played by fingering tremolo and } \\
\text { vocalised tone tremolo. }\end{array}$
\end{tabular}




\section{Analysis and Discussion}

\section{Sonic Exploration and Insight}

Multiphonics are typically performed with different combinations of fingering pitch notes and long vocalised tone notes (singing) with or without vibrato and glissandi (pitch bending). Based on the spectrogram analysis of multiphonics (Figure 6), the resultant frequency (a combination of frequencies generated from the vocalised tone and blowing into the alto recorder air column) showed stable and several missing harmonics or phantom harmonics. The resultant harmonics were easily exploited by the vocalised tone and air stream behaviour (speed and volume) or embouchure (Figure 7). Combinations of two or three playing techniques that manipulate both vocalised tone and lip-tongue embouchure have enabled the composer to discover five new extended techniques derived from multiphonics (Table 4).

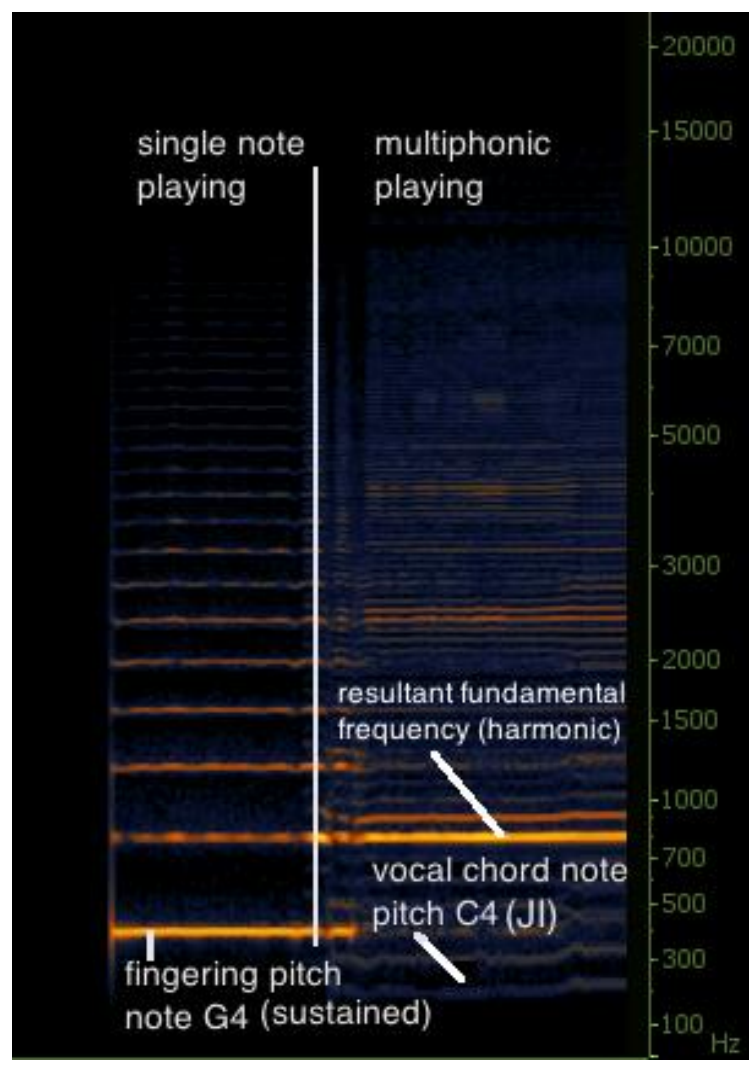

Figure 6. Spectrogram analysis (hertz, Hz) of single note and multiphonic playing with uniform fundamental frequencies (thick bright lines) from constant loudness of fingering pitch note G4 which later simultaneously played with vocalised tone note pitch $\mathrm{C} 4$ with just intonation (JI) 262 Hz. (Source: Ainolnaim Azizol, 2016) 


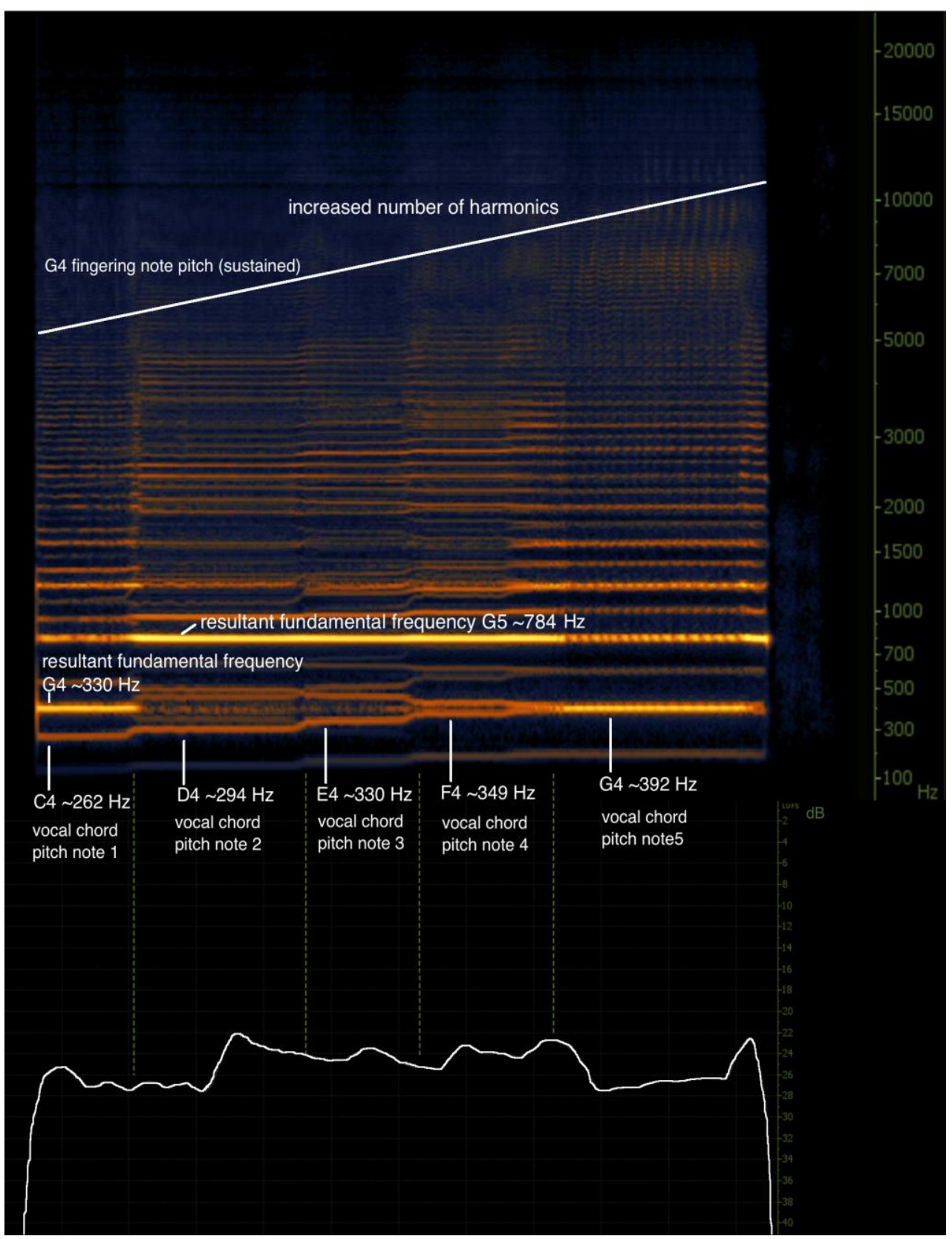

Figure 7. Spectrogram analysis (hertz, Hz) and loudness of multiphonics consist of sustained G4 fingering note pitch with five vocalised tone pitch notes (Source: Ainolnaim Azizol, 2016) 
Changes in the size of the window and foot hole opening using hand or other wind resistant materials have been used as conventional extended techniques for pitch and timbre manipulation. Spectrogram analysis (Figure 8) shows a single note pitch sound production at the foot hole with less blowing air or breathing noise produced slightly softer sound than the sound produced at head-window and midfingering holes (Figure 9). This has led to the new extended technique idea of manipulating the air movement going out from the recorder. The recorder can be prepared with a mini-size Elizabethan collar or E-collar (cone-like megaphone), made from a plastic or metal sheet installed outside the bore of headpiece along the alto recorder window (Figure 10) which enables the sound to be focused and projected towards stereo perception listeners at a particular vector, resulting to sound localisation or spatial effect at a 360-degree horizontal plane and a 180degree vertical plane.

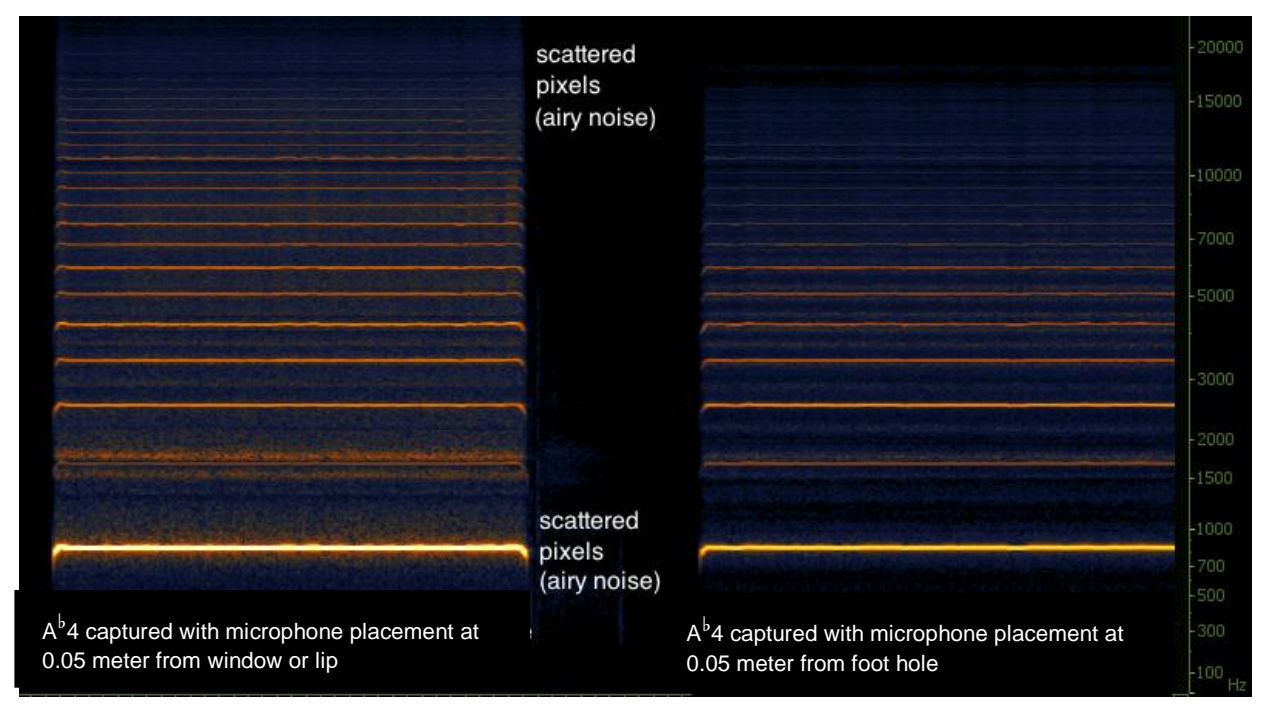

Figure 8. Spectrogram analysis indicating airy noise level projected at window and foot hole from the same sound source of $\mathrm{A}^{\mathrm{b}} 4$ (Source: Ainolnaim Azizol, 2016)

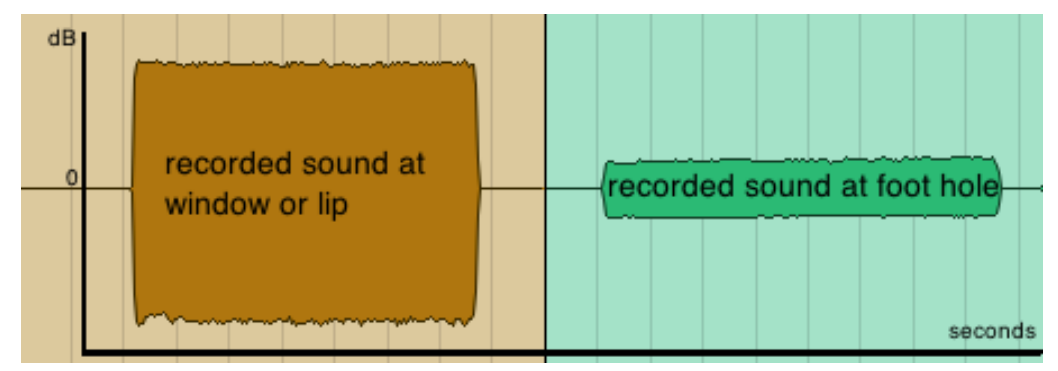

Figure 9. Loudness level (decibel, -dB) of $\mathrm{A}^{\mathrm{b}} 4$ (sound wave) with microphone placement at 0.05 meter from window or lip and foot hole (Source: Ainolnaim Azizol, 2016) 


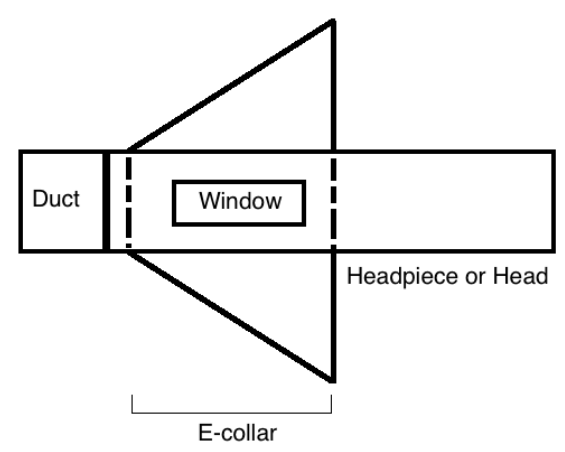

Figure 10. Top view of an alto recorder prepared with mini size E-collar made from plastic or metal sheet for alto recorder sound localization or spatial projection (Source: Ainolnaim Azizol, 2016)

Whistle tone is another conventional extended technique typically used for flute which can also be applied to alto recorder. Whistle tone (characterised as a thin, silky, transparent and airy sound with high harmonics) is generated by means of frequency modification of the air column's vibration. As reflected in the spectrogram analysis (Figure 11), three important determinants of the whistle tone quality are embouchure (lip tension and aperture) adjustment, airstream speed or pressure alteration and the length of the vibrating air column within the tube. This technique is played either by; 1) blowing normally at the mouthpiece and very carefully shading the window with a finger, which produces limited variations of high harmonics and 2) blowing with a transverse flute embouchure at the first hole (fingering hole number 1 near window) with free, alternate fingerings which produces variations of high harmonics. Conceivably, a combination of the aforementioned playing techniques would enable the whistle tone to be further explored and manipulated. Consequently, the composer has established a new extended technique of whistle tone by adapting transverse-flute-style playing in addition to timbral and dynamic fluctuation (wah-wah effects, a gradual loud-soft or terraced dynamics) through controlling of the size of the foot hole using hand or other wind resistant materials. 


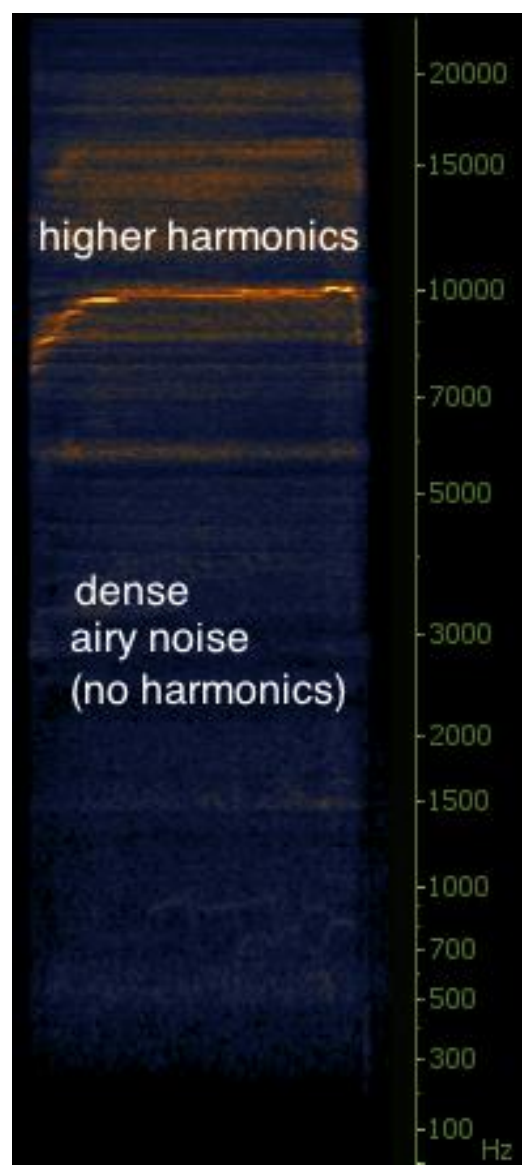

Figure 11. Spectrogram analysis of whistling tone technique with small numbers of high harmonics (with missing fundamental frequency) and dense airy noise (scattered pixels). (Source: Ainolnaim Azizol, 2016)

\section{Composition of Nadi Bumi}

The composition process of the piece began with recorder instrumentation study, which led to the sonic exploration of the instrument. However, while studying the alto recorder instrumentation and extended techniques, research and discussion on musical acoustics and musical aesthetics of alto recorder extended techniques were discovered to be very limited. Hence, this situation has elicited the interest to investigate and develop new extended techniques for alto recorder for application in the composition of Nadi Bumi. The sound idea development for the 7-minute piece emphasised 'tone gestures' and timbral changes, which involved spectral music techniques and timbral associations of ancient bone flute or whistle with recorder and primitive tone gestures (Figure 12). 


\section{Music duration: 7 minutes}

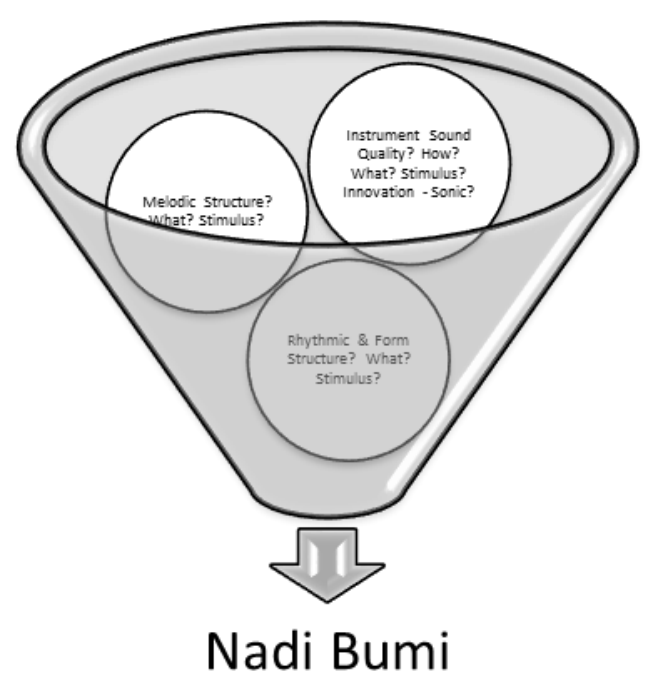

Figure 12. Research process of composing Nadi Bumi (Source: Ainonaim Azizol, 2016)

According to Juan G.R. (2008), tone as in sound is made of single or multiple sound waves with specific sonic characteristics such as loudness, articulations, and timbre. The idea of tone gestures classify and categorise the specific set of tones produced by the extended techniques and non-extended technique tones. This set of tones was organised similarly to the organising of pitches in a series of melodic gestures based on pitch-scale tonality function. These tones are described in the arrangement of low-high tone range, rather than specific tuning melodic intervals range in pitch-scale tonality function (Figure 13). Tone gestures consist of the vertical motion of tones between high and low registers and horizontal motion of rhythmic displacements, while melodic and harmonic gestures focus on one particular event of motion: the motion of pitches between a high and low register with a specific set of pitches based on tonality. Therefore, a flexible and boundless sonic landscape can be crafted on the musical canvas of Nadi Bumi through tone gestures.

Nadi Bumi used alto recorder due to the ethereal timbre quality compared to other recorder ranges. With a duration of 7 minutes, the piece consists of 7 systems (each 60 seconds in length) with two voice lines which both are played simultaneously by a recordist (solo). These staves were individually divided based on unique sonic ideas and the idiomatic expression of Fibonacci numbers ${ }^{3}(1,1,2,3$, 5,8 and 13). For example, the composer has decided to divide the fifth stave into 13 tone gesture cells, by which each cell holds unique tone gestures such as short pitches, different dynamic range, and octave register. 
The voicing lines of the alto recorder and definite pitch of humming-like vocal tones in the tone gesture cells are influenced by the frequential structure of the harmonic partial series constructed from the Schumann resonances (SR) spectrum peaks $(7.83 \mathrm{Hertz})$, as the fundamental frequency or first harmonic partial (f) of the extremely low frequency (ELF) of the electromagnetic resonance produced by lightning discharge between the ground and ionosphere. The frequency (7.83 Hertz) is multiplied by the harmonic partial numbers $(\mathrm{fx} 1, \mathrm{fx} 2, \mathrm{f} \times 3 \ldots)$ up to the octaves of the alto recorder voice range (Table 5). For example, overtone series, amplitude modulation or amplitude vibrato, frequency modulation and ring modulation are reflected by the peculiar, primitive and explorative sound of conventional and new alto recorder extended techniques. The timbral changes work between harmonic and melodic consonance-dissonance and tension-release of tone gestures in vertical and horizontal motion. The composer decided to use several new types of multiphonics discovered in this research in which the sound world is suitable for the sonic idea of the piece (Figure 14). The spatial extended techniques (E-collar) was not applied in the piece due to the unknown acoustic environment and stage setting of the music performance.
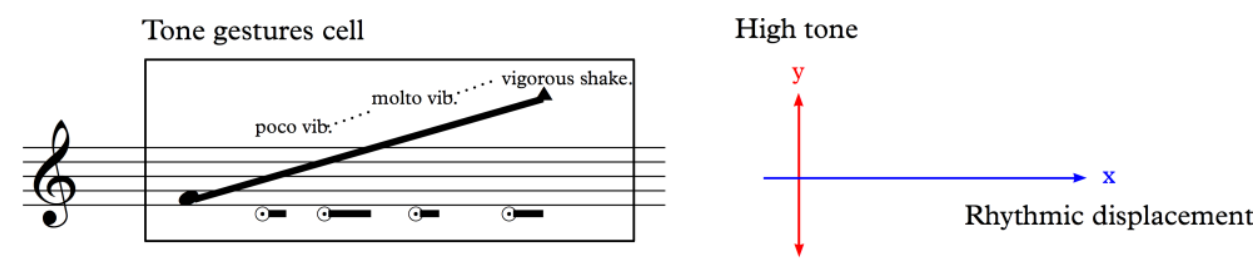

Low tone

High tone

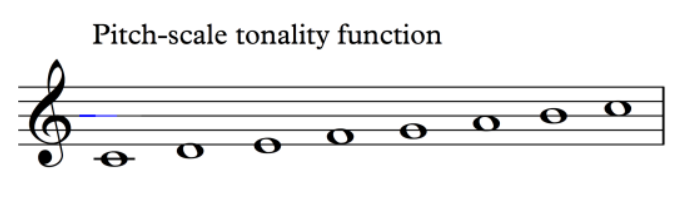

C3 $\begin{array}{lllllll}\text { D } 3 & \text { E3 } & \text { F3 } & \text { G3 } & \text { A3 } & \text { B3 } & \text { C4 } 4\end{array}$

Tonality: C major

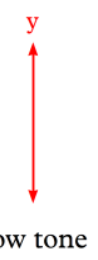

Figure 13. Tone gestures concept derived from pitch-scale tonality function (Source: Ainolnaim Azizol, 2016) 

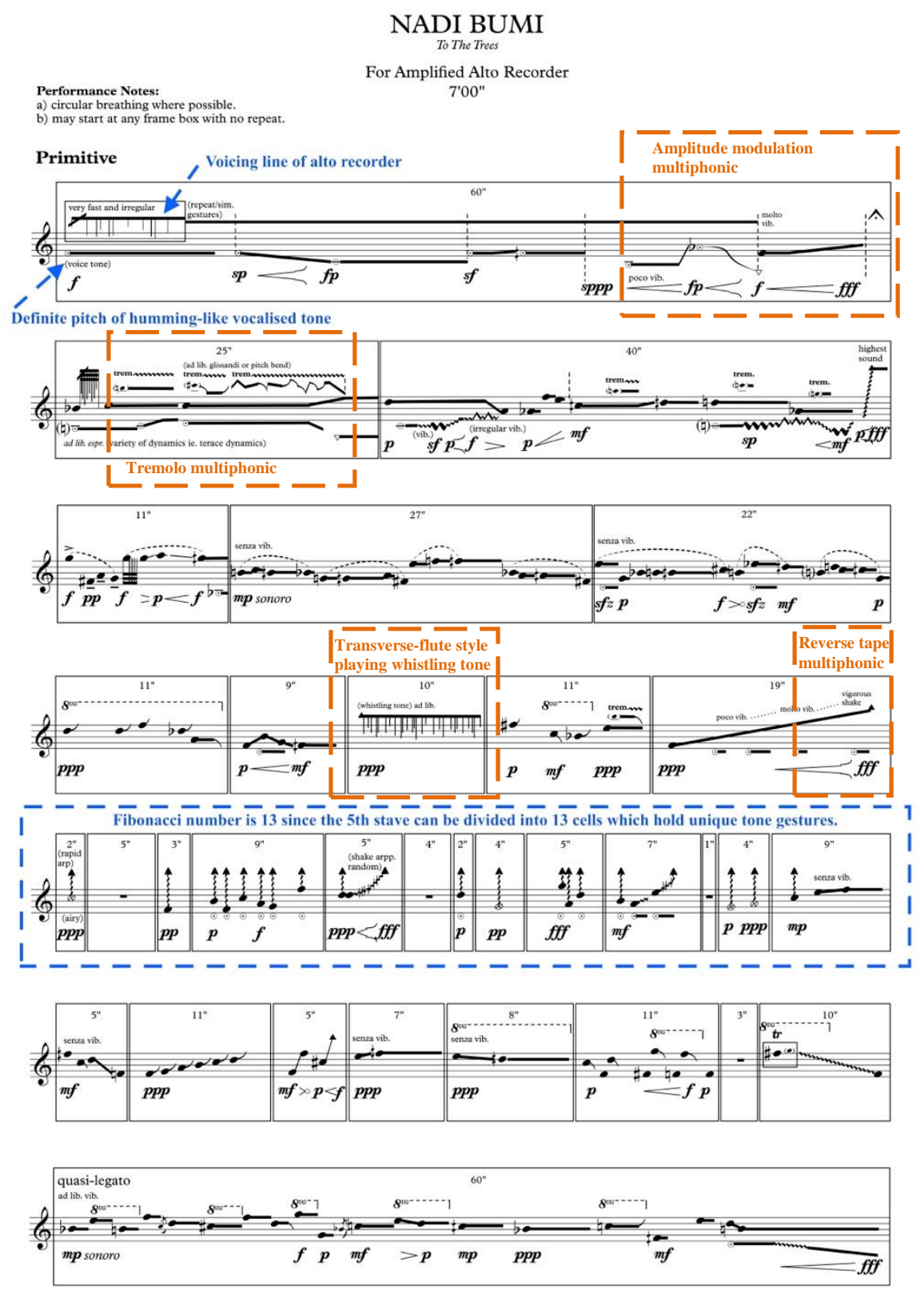

Figure 14. Fibonacci numbers in relation to number of tone gestures cells and selected new extended techniques used (Source: Ainolnaim Azizol, 2016) 
Table 5

Relationship of harmonic partials on Schumann Resonance fundamental frequency with alto recorder frequency and pitch range

\begin{tabular}{ccc|ccc}
$\begin{array}{c}\text { Harmonic } \\
\text { Partials } \\
\begin{array}{c}\text { Number } \\
(\mathbf{N})\end{array}\end{array}$ & $\begin{array}{c}\text { Fundamental } \\
\text { at 7.83Hz } \\
(\mathbf{N}) \text { in Hertz } \\
(\mathbf{H z})=\mathbf{A}\end{array}$ & & $\begin{array}{c}\text { Well-tempered } \\
\text { Tuning in Hertz } \\
(\mathbf{H z})=\mathbf{B}\end{array}$ & $\begin{array}{c}\text { Alto } \\
\text { Recorder } \\
\text { Pitch Note }\end{array}$ & $\begin{array}{c}\text { A-B in } \\
\text { Herts } \\
(\mathbf{H z})\end{array}$ \\
\hline 45 & 352 & $\approx$ & 349 & F4 & 3 \\
47 & 368 & $\approx$ & 370 & F\#4 & -2 \\
50 & 392 & $=$ & 392 & G4 & 0 \\
53 & 415 & $=$ & 415 & G\#4 & 0 \\
56 & 438 & $\approx$ & 440 & A4 & -2 \\
59 & 462 & $\approx$ & 466 & A\#4 & -4 \\
63 & 493 & $\approx$ & 494 & B4 & -1 \\
67 & 525 & $\approx$ & 523 & C5 & 2 \\
71 & 556 & $\approx$ & 554 & C\#5 & 2 \\
75 & 587 & $=$ & 587 & D5 & 0 \\
79 & 619 & $\approx$ & 622 & D\#5 & -3 \\
84 & 658 & $\approx$ & 659 & E5 & -1 \\
89 & 697 & $\approx$ & 699 & F5 & -2
\end{tabular}

\section{Conclusion}

The analysis, discussion, and discovery of seven possible new sonic qualities in extended techniques are conducted through scientific and artistic profile studies on the sound production of alto recorder and its conventional extended techniques. A mixture of multiple sound waves and other mechanical vibrations, including the manipulation of the alto recorder's acoustic properties, produced new tones which can be in pitched, un-pitched, musical and non-musical form. The idea and term of tone gestures were coined and used to substitute the pitch-scale tonality function in Nadi Bumi and previous work of the composer on duo trumpet in B-flat entitled fragments $I$. The concept of tone gestures gave two dimensions of sonic imaginary space. Future studies to explore and discover new extended techniques on prepared techniques for alto recorder and other recorder range (e.g. bass recorder and subbass recorder) are highly recommended to create continuity, fresh, alternative, creative and artistic profile for new recorder music composition. 


\section{Endnotes}

1 Just intonation (JI) is a musical tuning system having intervals that are acoustically (harmonically) pure.

${ }^{2}$ Equal temperament is a tuning system in which the frequency interval between every pair of adjacent notes has the same ratio. It is the common musical scale used for the tuning of pianos and other instruments of relatively fixed scale.

${ }^{3}$ The Fibonacci numbers appear in nature and in music. Notes in the scale of western music are based on natural harmonics that are created by ratios of frequencies. Ratios found in the first seven numbers of the Fibonacci series $(0,1,1,2,3,5,8)$ are related to key frequencies of musical notes.

\section{Acknowledgements}

The author would like to acknowledge Gertrud Kuhn (President of Association Flauto Dolce Lausanne, Switzerland) and Marc Pauchard (recordist for Nadi Bumi) for the indispensable opportunity and meaningful collaboration, and Mohamed Taufiq Omar (Research Assistant) who contributes substantially to the preparation of the manuscript. The research facilities and financial support provided by the Universiti Teknologi MARA are also duly acknowledged.

\section{References}

Ainolnaim, A. (2016). Nadi Bumi: Extended techniques for alto recorder \& science. Paper presented at the Second $\left(2^{\text {nd }}\right)$ International Performing Arts and Music Conference (IMPAC2016): Universiti Pendidikan Sultan Idris, Tanjung Malim, Perak, Malaysia. Retrieved from http://impac2016.upsi.edu.my/index.php/online-proceedings

Ainolnaim. A. (2016). Nadi Bumi for amplified alto recorder in F [Performed by Marc Pauchard. Recorded by RTS Espace 2 Radio]. New Recorder Music Festival 2016. Lausanne, Switzerland: L'Association Flauto Dolce.

AKG Acoustics Gmbh. (2015). AKG 451B Reference condenser vocal microphone. Retrieved from http://cloud.akg.com/10243/c451_manual.pdf.

Bali, J. (2013). Introduction to the avant-garde for recorder players. Budapest: Editio Musica Budapest.

Barata, A. (1988). Sources of information on woodwind multiphonics: An annotated bibliography. Perspectives of New Music, 26(1) 246-56. Retrieved from http://www.jstor.org/stable/833328.

Bennetts, K., Bousted, B., \& Bowman, P. (1988). The quarter-tone recorder manual. Celle: Edition Moeck 2084.

Boubaker, H. (2015). Leçons de respiration circulaire [Circular breathing lessons]. Retrieved from http://heddy.boubaker.free.fr/Respiration-Circulaire.shtml.

Burtner, M (2005). Making noise: Extended techniques after experimentalism. Retrieved from http://www.NewMusic.Box.org.

Clark, P. (1970). The recorder [sic.]. Recorder and Music Magazine, 3(7) 235-36. Retrieved from http://www.recordermagazine.co.uk/rm_index.htm. 
Chamberlain, N. (2011). Extended flute technique. [Video file]. Retrieved from https://www.youtube.com/watch?v=Kp9mm1zApSs

Dunn, J. (2001-2004). Audio precision application note \#5: Measurement techniques for digital audio. Oregon: Audio Precision, Inc. Retrieved from http://www2.electron. frba.utn.edu.ar/ jcecconi/Bibliografia/13\%20-\%20Medicion\%20de\%20

Amplificadores/Documentos/AudioPrecision_AN5_DigitalAudioMeasurement.pdf

Elder, S.A. (1964). Physicists and fipple flute at APL. Retrieved from http://www.jhuapl.edu/techdigest/views/pdfs/V03_N3_1964/V3_N3_1964_Elder.pdf

Goedhart, D. (2015). Het spelen van hedendaagse blokfluitmuziek [Playing contemporary recorder music]. Retrieved from http://www.angelfire.com/fl/flautonuovo/ Enieuws09.html.

Grossmann, V., \& Cesar, M. (2010). Developing a hybrid contrabass recorder: Resistances, expression, gestures and rhetoric. Proceedings from NIME 2010: The International Conference on New Interfaces for Musical Expression, 223-28. Sydney. Retrieved from https://www.researchgate.net/publication/254200082_Developing_a_Hybrid_ Contrabass_Recorder_Resistances_Expression_Gestures_and_Rhetoric

Hauwe, W. V. (1984-1992). The modern recorder player. 3 vols. London: Schott Edition 12150, 12270, 12361. Retrieved from http://www.read4freebooks.com/ recommendations-book/the-modern-recorder-player.

Hawkins, S. J. (1776). A general history of the science and practice of music. 5 vols. London: T. Paine \& Sons. Retrieved from http://imslp.org/wiki/A_General_ History_of_the_Science_and_Practice_of_Music_(Hawkins,_John).

Horringa, D. (1991). De electronische blokfluit - Een interview met Michael Barker [The Electronic Recorder, an Interview with Michael Barker]. Retrieved from http://www.angelfire.com/fl/flautonuovo/Enieuws03.html.

Juan G.R. (2008). The physics and pschopysics of music: An introduction (Fourth ed.). New York, NY: Springer.

Kientzy, M. (1982). Les sons multiples aux flütes à bec [Multiphonics on the Recorder]. Paris: Editions Salabert. Izotope. (2016). Izotope Insight. Retrieved from http://valdez.dumarsengraving.com/multiphonics.pdf

Lander, N.S. (1996). Recorder home page: Technique: Extended technique. Retrieved from http://www.recorderhomepage.net/technique/extended-technique/.

Lavry, D. (2004). Sampling theory for digital audio. Lavry Engineering, Inc. Retrieved from http://lavryengineering.com/pdfs/lavry-sampling-theory.pdf

Mayer-Spohn, U., \& Takahashi, K. (2014). The recorder map. Retrieved from http://recordermap.com/.

Mersenne, M. (1637). Seconde partie de l'harmonie universelle, livre cinqueisme. Des instruments à vent [Second part of "Harmonie universelle". Wind instruments]. Paris: Ballard. Retrieved from http://imslp.org/wiki/Harmonie_universelle_(Mersenne,_Marin).

Müller, H. (2015). Técnicas contemporâneas para flauta doce [Contemporary Techniques for Recorder]. Retrieved from http://www.helciomuller.mus.br/tecnicas.html.

O'Brien, E. and Haas, E. (1999). About Woods used to make recorders. Retrieved from http://www.vonhuene.com/topic.aspx?name=recorderwood.

O'Kelly, E. (1985). The recorder in twentieth-century music. Vol. 1: The recorder, its music and technique in the twentieth century; Vol. 2: A catalogue of twentieth-century recorder music. M.Phil., London: Goldsmith's College, University of London. 
O’Kelly, E. (1990). The recorder today. Cambridge: Cambridge University Press. Retrieved from https://books.google.com.my/books?id=zweJqOFJKz8C\&pg=PR4\&lpg=PR4\& $\mathrm{dq}=\mathrm{O} \% \mathrm{E} 2 \% 80 \% 99 \mathrm{Kelly},+\mathrm{E} .+(1990) .+$ The + Recorder + Today.\&source=bl\&ots $=0 \mathrm{WV}$ _4XTtXx\&sig=FxQqekokScCkwFzMd-XEMFnryY4\&hl=en\&sa=X\&ved=0ahUKEw i4x7iunKrYAhWCopQKHdPCDW0Q6AEIPjAE\#v=onepage\&q=O\%E2\%80\%99Kell y\%2C\%20E.\%20(1990).\%20The\%20Recorder\%20Today.\&f=false

O'Kelly, E. (1995). The recorder revival. II, The twentieth century and its repertoire. In Thomson, J.M., \& Rowland-Jones, A, The Cambridge Companion to the Recorder (66-152). Cambridge: Cambridge University Press.

Rechberger, H. (1987). Die blockflöte in der zeitgenössischen Musik [The recorder in contemporary music]. Typescript. Finnish Music Information Centre: Helsinki.

Roll-Hansen, N. (2003). Why the distinction between basic (theoretical) and applied (practical) research in the politics of science (Report). The London School of Economics and Political Science. Retrieved from http://www.lse.ac.uk/CPNSS/research/concludedResearchProjects/ContingencyDisse ntInScience/DP/DPRoll-HansenOnline0409.pdf

Rowland-Jones, A. (1993). Putting the clock back. The Recorder: Australia's Journal of Recorder \& Early Music, 17(12), 12.

Sarah Jeffery / Team Recorder. (2017). Intro to contemporary / extended techniques for recorder! Team recorder. [Video file]. Retrieved from https://www.youtube.com/watch? $=$ meaESDXNmm0

Schmidt, U. (1981). Notation der neuen Blockflötenmusik: Ein Überblick [Notation of new recorder music: an overview]. Celle: Moeck. Retrieved from https://searchworks.stanford.edu/view/1221736.

Sebastiani, C. (1563). Bellum musicale inter plani et mensuralis cantus reges, de principatu in musicae prouincia obtinendo, con tendentes. Strassburg: Pauli Machaeropoei [Messerschmidt]. Retrieved from http://imslp.org/wiki/Bellum_musicale_(Sebastiani, -Claudius).

TheModernRecorder. (2012). Louis Andriessen: Sweet (1964). [Video file]. Retrieved from https://www.youtube.com/watch?v=NB0GtseEvQc

TheModernRecorder. (2013). Ryohei Hirose: Meditation (1975). [Video file]. Retrieved from https://www.youtube.com/watch?v=sbqFk07DPtE

Troman, R. (1985). Souffle [Breath]. Flûte à bec \& instruments anciens, 13/14, 15.UCL. (2003). Acoustics of Speech and Hearing. Retrieved from http://www.phon.ucl.ac.uk/courses/spsci/acoustics/week1-10.pdf.

Uffenbach, Z.C. (1934). London in 1710: From the travels of Zacharias Conrad Von Uffenbach. London: Faber \& Faber.

Wells, P. G. (2000). Giving the fingers. I, Conventions in the Notation of Contemporary Recorder Music. Recorder Magazine, 20(2): 59-62.

Yorita, R. (2014). Using Spectral Analysis to Evaluate Flute Tone Quality. The Faculty of California Polytechnic State University San Luis Obispo. Retrieved from http://digitalcommons.calpoly.edu/cgi/viewcontent.cgi? article=2422\&context=theses. 


\section{Biography}

Ainolnaim Azizol is a Malaysian pianist, composer and sound artist. He received his Masters of Music in Music Composition at the Royal Birmingham Conservatoire and his Bachelor of Music in Piano Performance and Pedagogy at Universiti Sains Malaysia. Since 2010, he has written a collection of compositions that incorporate traditional elements from both local and foreign music in a contemporary music style. His award-winning compositions such as C-lat, Badang!!!!, Fragments, Nocturne, Konstruktif, and Nadi Bumi, have been performed in Malaysia, Indonesia, Japan, Singapore, Portugal, Switzerland, Germany and United Kingdom. Ainolnaim currently works as a lecturer in music composition at the Faculty of Music, Universiti Teknologi Mara. Visit http://www.ainolnaim.wordpress.com for more information about the author. 